\title{
Chromogranin Gene
}

National Cancer Institute

\section{Source}

National Cancer Institute. Chromogranin Gene. NCI Thesaurus. Code C21200.

Chromogranin Genes encode Chromogranins, widespread heterogenous acidic soluble glycopropolypeptide constituents of neuroendocrine and chromaffin cell secretory granules that elicit an effect themselves or serve as precursors to many biologically active peptides. $(\mathrm{NCl})$ 